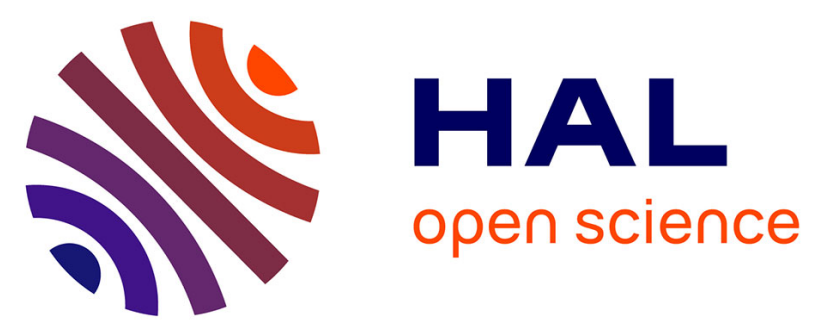

\title{
The Influence of Metakaolin on Limestone Reactivity in Cementitious Materials
}

\author{
Guillermo Puerta-Falla, Magdalena Balonis, Gwenn Le Saout, Narayanan \\ Neithalath, Gaurav Sant
}

\section{- To cite this version:}

Guillermo Puerta-Falla, Magdalena Balonis, Gwenn Le Saout, Narayanan Neithalath, Gaurav Sant. The Influence of Metakaolin on Limestone Reactivity in Cementitious Materials. 1st International Conference on Calcined Clays for Sustainable Concrete, Jun 2015, Zurich, Switzerland. pp.11-19, 10.1007/978-94-017-9939-3_2 . hal-02914818

\section{HAL Id: hal-02914818 \\ https://hal.science/hal-02914818}

Submitted on 10 Nov 2021

HAL is a multi-disciplinary open access archive for the deposit and dissemination of scientific research documents, whether they are published or not. The documents may come from teaching and research institutions in France or abroad, or from public or private research centers.
L'archive ouverte pluridisciplinaire HAL, est destinée au dépôt et à la diffusion de documents scientifiques de niveau recherche, publiés ou non, émanant des établissements d'enseignement et de recherche français ou étrangers, des laboratoires publics ou privés.

\section{다)(1) $(5$}

Distributed under a Creative Commons Attribution - NonCommerciall 4.0 International 


\title{
The Influence of Metakaolin on Limestone Reactivity in Cementitious Materials
}

\author{
Guillermo Puerta-Falla, Magdalena Balonis, Gwenn Le Saout, \\ Narayanan Neithalath and Gaurav Sant
}

\begin{abstract}
Recent studies have demonstrated that in the presence of limestone $\left(\mathrm{CaCO}_{3}\right)$, carbonate-AFm phases (i.e., hemi- and/or mono-carboaluminate) may be stabilized at the expense of sulfate-AFm, which is more commonly found in cement systems. This suggests that enhancing AFm phase formation may be a novel way of incorporating increased quantities of limestone as a reactive component in cementbased systems. Often, in an ordinary portland cement (OPC), the quantity of the AFm hydrates formed is limited by the availability of aluminum. Therefore, as means of enhancing AFm phase formation, this paper evaluates metakaolin addition to determine how it affects limestone reactions and carbonate-AFm formation in the OPC systems. The results of a multi-method study including: X-ray diffraction with Rietveld refinement (QXRD), strength measurements, thermogravimetric analysis, and thermodynamic calculations are used to quantify solid phase constitutions, and the extent of limestone that has been consumed in reaction. Obtained results suggest that pozzolanic reactions which occur when metakaolin is used as an aluminous source are observed to be beneficial in offsetting the dilutive effects of OPC replacement noted in blended cement formulations.
\end{abstract}

\author{
G. Puerta-Falla $\cdot$ G. Sant $(\varangle)$ \\ Department of Civil and Environmental Engineering, University of California, \\ Los Angeles, CA, USA \\ e-mail: gsant@ucla.edu \\ M. Balonis \\ Department of Materials Science and Engineering, University of California, \\ Los Angeles, CA, USA \\ M. Balonis \\ Institute for Technology Advancement, University of California, \\ Los Angeles, CA, USA \\ G. Le Saout \\ Centre des Matériaux de Grande Diffusion (CMGD), École des Mines d'Alès, \\ Alès cedex, France \\ N. Neithalath \\ School of Sustainable Engineering and the Built Environment, \\ Arizona State University, Tempe, AZ, USA
}




\section{Introduction}

$\mathrm{CO}_{2}$ pressures facing the construction industry are providing an increasing impetus to reduce the use of ordinary portland cement (OPC) as the primary binder phase in concrete [1]. Towards reducing OPC use, emphasis has been placed on replacing OPC with supplementary cementitious materials (SCMs) in the form of: fly ash, blast furnace slags, silica fume, etc. [2,3]. While capable of providing suitable properties, quantities of common SCMs available to replace OPC, are often, especially at local scales, inadequate to satiate the desired OPC replacement demand [4]. Due to concerns of the limited/localized availability of SCMs, there is interest in using limestone $\left(\mathrm{CaCO}_{3}\right)$, an abundant mineral, to reduce the clinker factors of OPC, and thus OPC use in concrete. The replacement of OPC by limestone induces a variety of effects ranging from: (a) dilution and strength reduction $[5,6]$, to (b) accelerated hydration at early ages that results from the socalled filler effects [7]. Of these effects, dilution, i.e., the reduction in strength that accompanies OPC replacement is a considerable issue, as technologically this is the most significant limitation which has ensured that, in practice, OPC replacement by $\mathrm{CaCO}_{3}$ remains limited [8]. OPC is comprised of four main phases tricalcium silicate $\left(\mathrm{C}_{3} \mathrm{~S}\right)$, dicalcium silicate $\left(\mathrm{C}_{2} \mathrm{~S}\right)$, tricalcium aluminate $\left(\mathrm{C}_{3} \mathrm{~A}\right)$ and the ferrite $\left(\mathrm{C}_{4} \mathrm{AF}\right)$ phases, wherein the kinetics of hydration of each phase differs from the others ${ }^{1}$ [9]. Hydration of the $\mathrm{C}_{3} \mathrm{~A}$ in the presence of sulfate ions, provided by gypsum $\left(\mathrm{CS}_{2} \mathrm{H}_{2}\right)$, forms ettringite $\left(\mathrm{C}_{6} \mathrm{~A} \overline{S_{3}} \mathrm{H}_{32}, \mathrm{AFt}\right)$ at early ages and the monosulfoaluminate $\left(\mathrm{C}_{4} \mathrm{~A} \overline{\mathrm{S}} \mathrm{H}_{12}, \mathrm{SO}_{4}-\mathrm{AFm}, \mathrm{Ms}\right)$, at later ages when gypsum is exhausted. However, in cases where carbonate ions may be present, e.g. as provisioned by the dissolution of limestone, $\mathrm{C}_{3} \mathrm{~A}$ reacts with such species to form the $\mathrm{CO}_{3}-\mathrm{AFm}$ phases instead of $\mathrm{SO}_{4}-\mathrm{AFm}$ and ettringite is stabilized to accommodate sulfate ions [1012]. In general, monocarboaluminate $\left(\mathrm{C}_{4} \mathrm{~A} \overline{\mathrm{C}} \mathrm{H}_{11}, \mathrm{Mc}\right)$ forms when there is an abundance of the (calcium) carbonate source present, and hemicarboaluminate $\left(\mathrm{C}_{4} \mathrm{~A}_{\mathrm{C}_{0.5}} \mathrm{H}_{12}, \mathrm{Hc}\right)$ forms in the case of carbonate-deficient conditions [12]. In typical OPCs, the aluminate (mainly $\mathrm{C}_{3} \mathrm{~A}$ ) phase content is regulated by governing standards [10]. This ensures that the extent of $\mathrm{CaCO}_{3}$ that can react in a typical OPC is quite small and in the range of $2-5 \%$ (by mass) [12]. As such, if it is desirable to increase $\mathrm{CaCO}_{3}$ reactivity and thus OPC replacement levels, it is necessary to enhance the quantity of aluminous phases that can provide sufficient $\mathrm{Al}$ $(\mathrm{OH})_{4}^{-}$(aluminate) species, which under conditions of portlandite saturation would react with $\mathrm{CaCO}_{3}$ to produce the $\mathrm{CO}_{3}$-AFm phases. In this work metakaolin (MET) is evaluated as aluminous agent which can extend the limestone reactivity in portland cement systems.

\footnotetext{
${ }^{1}$ Standard cement chemistry notation is used: $\mathrm{C}=\mathrm{CaO}, \mathrm{S}=\mathrm{SiO}_{2}, \mathrm{~A}=\mathrm{Al}_{2} \mathrm{O}_{3}, \mathrm{~F}=\mathrm{Fe}_{2} \mathrm{O}_{3}, \mathrm{H}=\mathrm{H}_{2} \mathrm{O}$, $\bar{S}=\mathrm{SO}_{3}$ and $\bar{C}=\mathrm{CO}_{2}$.
} 
Table 1 The oxide composition of materials utilized in this study as determined by X-ray fluorescence (XRF)

\begin{tabular}{l|l|l}
\hline Oxide (\%) & Type I/II OPC & MET \\
\hline $\mathrm{SiO}_{2}$ & 20.54 & 51.36 \\
\hline $\mathrm{Al}_{2} \mathrm{O}_{3}$ & 4.97 & 47.60 \\
\hline $\mathrm{Fe}_{2} \mathrm{O}_{3}$ & 3.10 & 0.39 \\
\hline $\mathrm{CaO}$ & 65.75 & 0.02 \\
\hline $\mathrm{MgO}$ & 2.43 & 0.09 \\
\hline $\mathrm{SO}_{3}$ & 2.75 & 0.08 \\
\hline $\mathrm{Na}_{2} \mathrm{O}$ & 0.18 & 0.28 \\
\hline $\mathrm{K}_{2} \mathrm{O}$ & 0.29 & 0.18 \\
\hline
\end{tabular}

\section{Materials and Methods}

An ASTM C150 compliant Type I/II ordinary portland cement (OPC) and commercially available limestone (nominally pure: $>95 \% \mathrm{CaCO}_{3}, \mathrm{~d}_{50}=3 \mu \mathrm{m}$ ) were used. The oxide compositions of the OPC and metakaolin (MET) are presented in Table 1. A series of cementitious mixtures were prepared using de-ionized (DI) water at a fixed water-to-solids ratio $(w / s=0.45)$ as described in ASTM C305. The series of mixtures produced comprised of: (a) plain OPC, pastes in which: (b) $30 \%$ of the OPC is replaced by limestone ${ }^{2}$ (c) 5-to-15\% of the OPC is replaced in $5 \%$ increments by MET (d) 5-to-15\% of the OPC is replaced in $5 \%$ increments by MET and an additional $30 \%$ of the OPC is then replaced by limestone.

Compressive strength measurements were carried out at 90 days using cubic specimens $(50 \mathrm{~mm} \times 50 \mathrm{~mm} \times 50 \mathrm{~mm})$ cured at $25 \pm 1{ }^{\circ} \mathrm{C}$ in lime water as described in ASTM C109 [8].

For thermal analysis (TG/DTG) a Perkin Elmer STA 6000 thermal analyzer with a Pyris data acquisition interface was used to determine solid phase quantities in cementitious mixtures.

To arrest hydration, solvent exchange was as described by Zhang and Scherer [13]. Quantitative X-ray diffraction analyses were carried out on powdered cementitious mixtures at desired ages using a Bruker D8 Advance diffractometer using $\mathrm{Cu}-\mathrm{K} \alpha(\lambda=1.54 \AA)$ radiation. Care was taken to minimize preferred orientation errors by texturing the sample surface, and using a rotating sample stage. $\mathrm{X}$ ray structure information for the relevant anhydrous and hydrated crystalline phases was sourced from standard databases or from the literature [14, 15]. Rietveld analysis was carried out using the X'Pert HighScorePlus $\subset$ [16].

Thermodynamic calculations were carried out using a geochemical speciation code, GEMS-PSI: version 2.3.1 [17]. Thermodynamic data of solid and aqueous

\footnotetext{
${ }^{2}$ All replacements in this study are performed on a mass basis; some pastes were prepared with quartz instead of limestone to enable comparison of compression strength for blends containing reactive component (limestone) versus inert filler (quartz).
} 
species are sourced from the GEMS-PSI database, and amended with additional information relevant to cementitious systems [12]. Calculations were performed under conditions of 1 bar, $25{ }^{\circ} \mathrm{C}$ and $\mathrm{CO}_{2}$-free air.

\section{Results and Discussion}

As showed on Fig. 1, the replacement of OPC by metakaolin results in improved strength. Such beneficial effects of metakaolin addition, have also been highlighted by Vance et al. [18, 19] and Antoni et al. [20] and attributed to the pozzolanic character of metakaolin, and the formation of the $\mathrm{Hc} / \mathrm{Mc}$ phases. This is significant in that in spite of very substantial reductions in the cement factor (CF), mechanical properties near equivalent to the pure OPC mixtures can be achieved. Figure 2 shows representative DTG traces at 90 days, and the portlandite content normalized by the cement factor (CF) for metakaolin containing mixtures. It is noted that portlandite contents of a given mixture decrease with increasing OPC replacement by metakaolin, even when dilution is accounted for. This is indeed expected due to the pozzolanic nature of metakaolin, which would consume lime to form a low(er) $\mathrm{Ca} / \mathrm{Si}$ (and potentially higher $\mathrm{Al}$-substituted) $\mathrm{C}-\mathrm{S}-\mathrm{H}$ phase which ensures that metakaolin containing mixtures show reduced decreases in compressive strength, in spite of the substantial OPC replacement. Figure 3 shows XRD patterns for the metakaolin containing mixtures after 90 days of hydration. It is noted that the portlandite content of a given mixture, in both limestone deficient/excess cases, reduces with increasing metakaolin content. Mc exists as the dominant phase, only when excess limestone is added to the system.

(a)

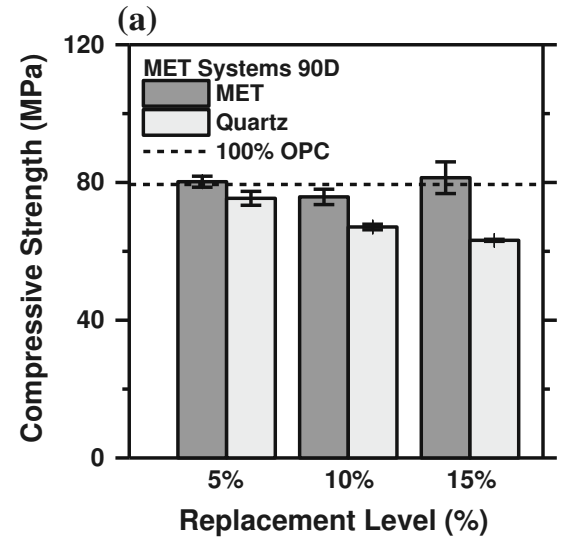

(b)

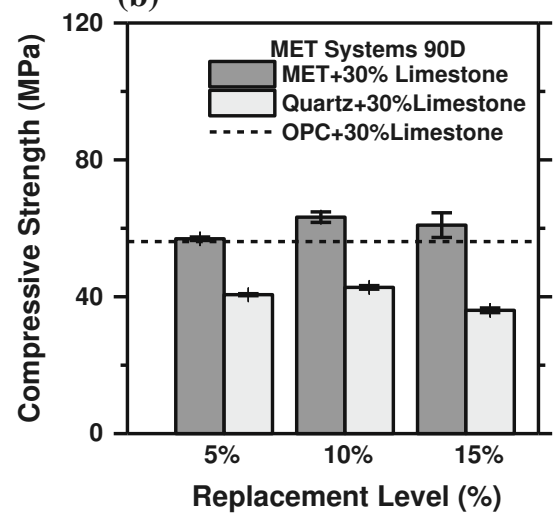

Fig. 1 Compressive strength at 90 Days for: a OPC systems b OPC $+30 \%$ Limestone systems, at different levels of replacement by metakaolin $(M E T)$; results compared against quartz which is not reactive and acts as inert filler 
(a)

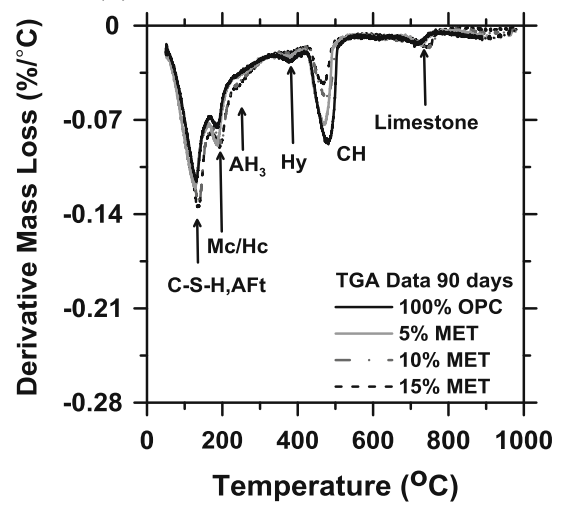

(c)

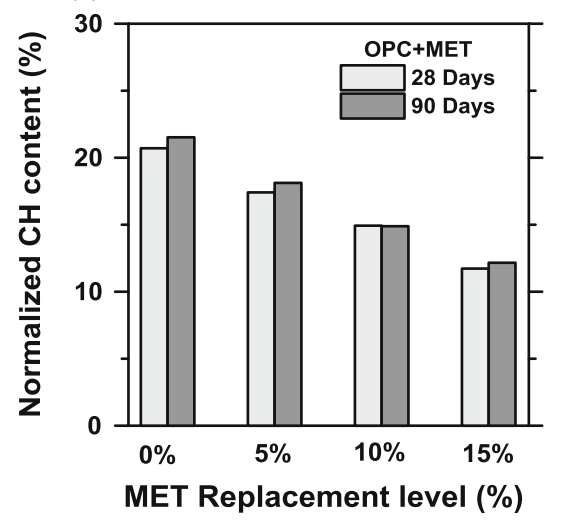

(b)

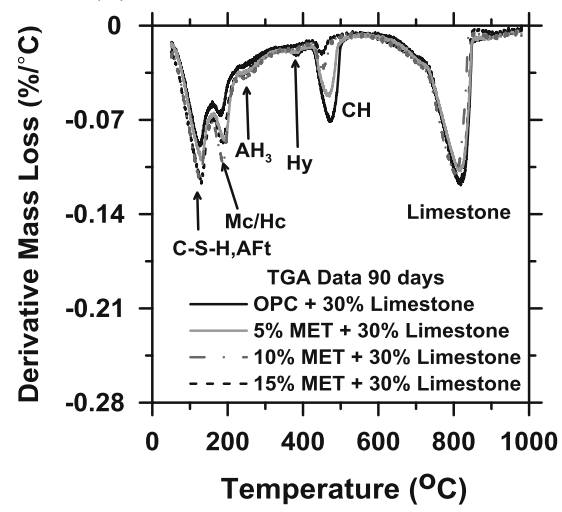

(d)

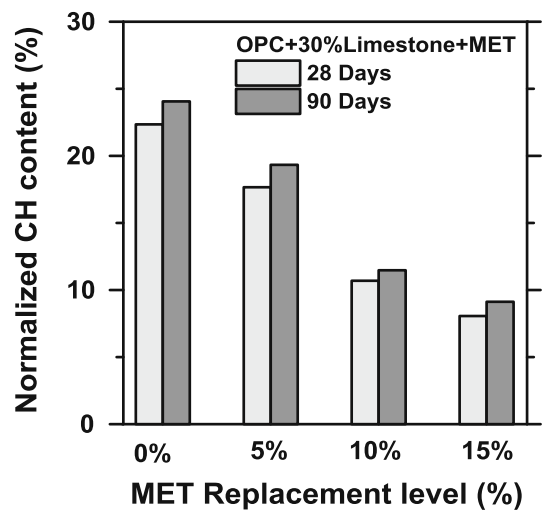

Fig. 2 Representative DTG curves for OPC mixtures for: a 0-to-15 \% MET replacement, b 0-to$15 \%$ MET replacement with additional $30 \%$ of limestone dosed by OPC replacement. The normalized (by $\mathrm{CF}$ ) portlandite contents for OPC mixtures for: $\mathbf{c} 0$-to- $15 \%$ MET replacement, $\mathbf{d} 0$ to-15\% MET replacement with additional $30 \%$ of limestone dosed by OPC replacement. The portlandite contents were determined by thermal analysis (TGA/DTG)

When only limestone intrinsic to the OPC (limestone deficient system) is present, Mc is stabilized only when no metakaolin is added. However, when OPC is replaced by metakaolin, in increasing proportion, $\mathrm{Hc}$ is stabilized as stable and dominant phase. This is in line with the observations made by Antoni et al. [20] and Vance et al. $[18,19]$. Contents of the $\mathrm{CO}_{3}-\mathrm{AFm}$ (i.e., $\mathrm{Hc} / \mathrm{Mc}$ ) phases, reflect trends in limestone consumption. More $\mathrm{CO}_{3}-\mathrm{AFm}$ phases form with increasing metakaolin content, and when excess limestone is present. It should be noted that while these trends follow evolutions in the equivalent $\mathrm{CO}_{2} / \mathrm{Al}_{2} \mathrm{O}_{3}$ ratio, limestone reaction is limited, likely on account of its low dissolution rate. In spite of the near consumption of portlandite, e.g., in the $15 \%$ metakaolin mixture containing excess limestone, strätlingite is not observed in the XRD patterns. It was noted that 
Fig. 3 XRD patterns for the plain (100\% OPC), limestone enriched (30\% OPC replacement by limestone) and MET enriched mixtures composed for limestone deficient and excess conditions.

Hemicarboaluminate $(H c)$, monocarboaluminate $(M c)$, portlandite $(\mathrm{CH})$, ettringite $(A F t)$ and hydrogrossular $(H y)$

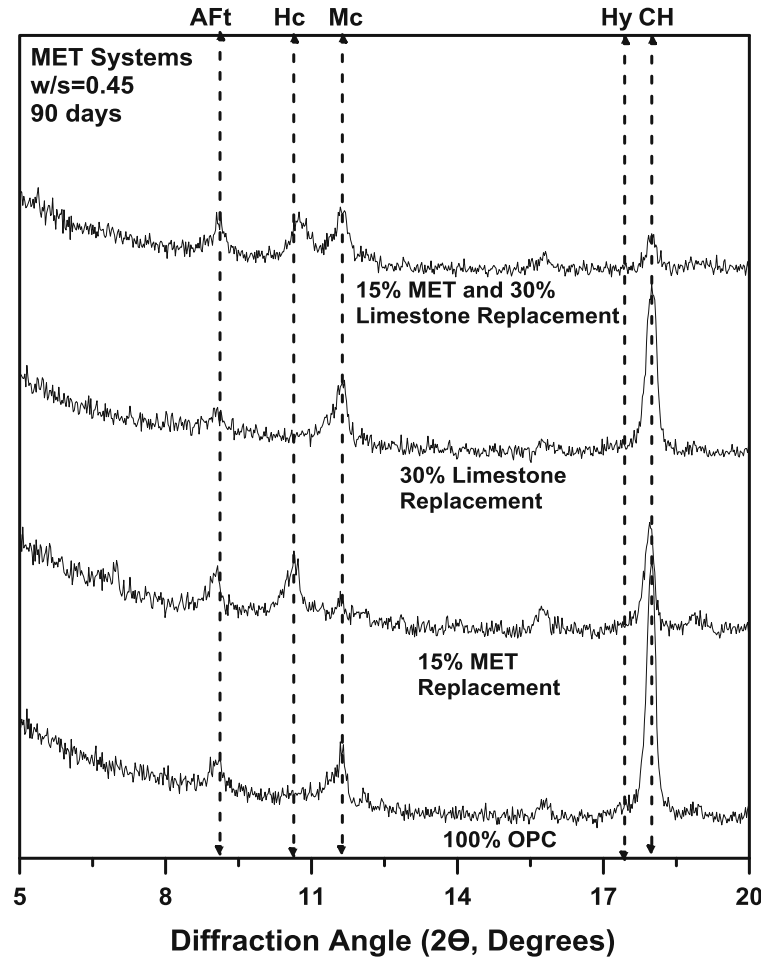

ettringite is present in both the deficient and excess limestone cases, wherein the release of sulfate ions, due to preferred $\mathrm{CO}_{3}{ }^{2-}$ ion uptake into the AFm phase, stabilizes ettringite in these systems. Figure 4 shows volumetric phase assemblages, calculated using GEMS, for $15 \%$ OPC replacement by metakaolin in either limestone deficient or excess conditions. The systems presented show (determined by the portlandite match-point from TGA data) a degree of metakaolin reaction of 37 and $31 \%$, in limestone deficient and excess scenarios respectively.

Due to pozzolanic reaction, metakaolin ensures consumption of lime and increased formation of $\mathrm{C}-\mathrm{S}-\mathrm{H}$ formed, albeit, of a lower $\mathrm{Ca} / \mathrm{Si}$ ratio and potentially also higher $\mathrm{Al}$ substitution. In agreement with $\mathrm{XRD}$ data, both $\mathrm{C}_{2} \mathrm{ASH}_{8}$ and Hydrogrossular phases are not predicted to form for relevant levels of metakaolin reaction. In contrast to the observations herein, XRD data of Antoni et al. [20] showed the presence of $\mathrm{C}_{2} \mathrm{ASH}_{8}$ and portlandite in coexistence with each other. While this is in violation of thermodynamic phase relations established by Damidot et al. [21], it may be on account of the somewhat higher metakaolin contents used in their study, or inhomogeneous reaction zones. This discrepancy could however, also be on account of uncertainties in determination of solubility data, small variations in which could alter stability fields dramatically. For example, as noted in the simulations shown herein (Fig. 4), strätlingite is predicted to form only when portlandite is consumed. When only limestone intrinsic to the OPC is present (see 

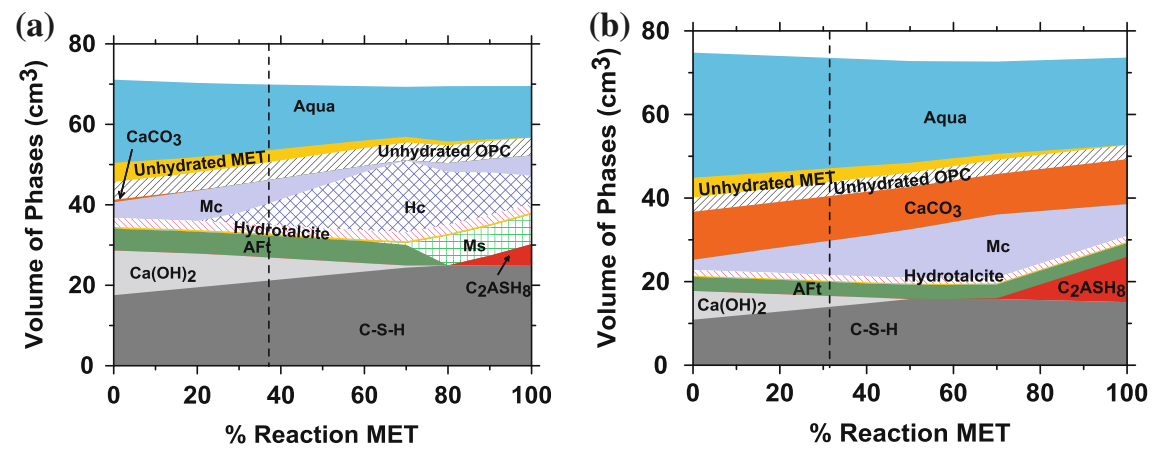

Fig. 4 Phase assemblages calculated using GEMS by incremental reaction of MET for a $15 \%$ MET and $\mathbf{b} 15 \%$ MET and additional $30 \%$ limestone replacement of OPC. Monosulfoaluminate $(M s)$, ettringite $(A F t)$, monocarboaluminate $(M c)$, hemicarboaluminate $(\mathrm{Hc})$, strätlingite $\left(\mathrm{C}_{2} \mathrm{ASH} \mathrm{H}_{8}\right)$, and hydrotalcite $\left(M_{4} A H_{10}\right)$ are denoted. The dashed lines locate the estimated phase assemblage and MET degree of hydration, after 90 days

Fig. 4a), at low levels of metakaolin reaction, Mc is stabilized. With the passage of time and increase in metakaolin reaction the phase relation changes and $\mathrm{Hc}$ becomes dominant with $\mathrm{Mc}$ existing as the minor $\mathrm{CO}_{3}-\mathrm{AFm}$ phase. For the degree of metakaolin reaction ascertained herein, Mc and Hc appear to exist in equivalent volumetric quantities, though on a mass basis this would translate to a larger quantity of $\mathrm{Mc}$ (the denser $\mathrm{CO}_{3}$-AFm phase), in contrast to the XRD data shown in Fig. 3. While this may indicate that the ascertained degree of metakaolin reaction is lower than reality, it may also suggest kinetic restraint in the formation of $\mathrm{Hc}$, from the Mc, Ms and portlandite (or vice versa depending on the chemical environment).

When excess limestone is present, Mc is predicted to be the dominant AFm phase (Fig. 4b). This is once again in contrast to the XRD observations in Fig. 3, where even under limestone excess conditions, when (15\%) metakaolin is present, $\mathrm{Hc}$ and $\mathrm{Mc}$ are noted to coexist; the reasoning for which is discussed above. It is seen that, at any degree of metakaolin reaction, a large quantity of limestone remains unreacted, ensuring modest levels of $\mathrm{Hc} / \mathrm{Mc}$ formation. This leads to the idea that the compensation in mechanical properties (see Fig. 1), produced by the combined replacement of OPC, by limestone and metakaolin, is dominantly on account of the pozzolanic nature of metakaolin and less due to the formation of $\mathrm{CO}_{3}$-AFm phases.

\section{Conclusions}

Metakaolin was evaluated in blended binder formulations in terms of its ability to enhance the reaction of limestone in cementitious systems. Such enhancements in limestone reaction are provoked by systematic manipulation of the binder 
chemistry, e.g., in terms of the $\mathrm{SO}_{3} / \mathrm{Al}_{2} \mathrm{O}_{3}$ and $\mathrm{CO}_{2} / \mathrm{Al}_{2} \mathrm{O}_{3}$ ratios of the binder. It is noted that in spite of the provision of sufficient aluminium, calcium and water, the extent of limestone reacted is limited, mostly on account of its low reactivity (i.e., dissolution rate, and solubility). Due to reasonable (reactive) aluminum content metakaolin has shown to increase limestone reactivity and resulting formation of the $\mathrm{CO}_{3}$-AFm (hemi- and/or mono-carboaluminate). On the account of its pozzolanic nature, it is also effective at ensuring strength equivalence, or improvement (in spite of reductions in the OPC content) as compared to the pure OPC formulations.

Acknowledgments Authors acknowledge full financial support provisioned by the NSF (CMMI: 1066583).

\section{References}

1. Concrete for the Environment.: Published on behalf of the nordic network concrete for environment by SP Swedish national testing and research institute. Boras, June 2003

2. Lothenbach, B., Scrivener, K.L., Hooton, R.D.: Supplementary cementitious materials. Cem. Concr. Res. 41, 1244-1256 (2011)

3. Fernandez, R., Martirena, F., Scrivener, K.L.: The origin of the pozzolanic activity of calcined clay minerals: A comparison between kaolinite, illite and montmorillonite. Cem. Concr. Res. 41, 113-122 (2011)

4. Schneider, M., Romer, M., Tschudin, M., Bolio, H.: Sustainable cement production-present and future. Cem. Concr. Res. 41, 642-650 (2011)

5. Sato, T., Beaudoin, J.J.: Effect of nano-CaCO3 on hydration of cement containing supplementary cementitious materials. Adv. Cem. Res. 23, 1-29 (2010)

6. Kumar, A., Oey, T., Kim, S., Thomas, D., Badran, S., Li, J., Fernandes, F., Neithalath, N., Sant, G.: Simple methods to estimate the influence of limestone fillers on reaction and property evolution in cementitious materials. Cem. Concr. Compos. 42, 20-29 (2013)

7. Oey, T., Kumar, A., Bullard, J.W., Neithalath, N., Sant, G.: The filler effect: the influence of filler content and surface area on cementitious reaction rates. J. Am. Ceram. Soc. 96, 19781990 (2013)

8. Annual book of ASTM standards.: American Society for Testing \& Materials (2004)

9. Taylor, H.F.W.: Cement chemistry. Thomas Telford, London (1997)

10. Matschei, T., Lothenbach, B., Glasser, F.P.: The role of calcium carbonate in cement hydration. Cem. Concr. Res. 37, 551-558 (2007)

11. Lothenbach, B., Le Saout, G., Gallucci, E., Scrivener, K.L.: Influence of limestone on the hydration of Portland cements. Cem. Concr. Res. 38, 848-860 (2008)

12. Matschei, T., Lothenbach, B., Glasser, F.P.: Thermodynamic properties of Portland cement hydrates in the system $\mathrm{CaO}-\mathrm{Al} 2 \mathrm{O} 3-\mathrm{SiO} 2-\mathrm{CaSO} 4-\mathrm{CaCO} 3-\mathrm{H} 2 \mathrm{O}$. Cem. Concr. Res. 37, 1379-1410 (2007)

13. Zhang, J., Scherer, G.W.: Comparison of methods for arresting hydration of cement. Cem. Concr. Res. 41, 1024-1036 (2011)

14. American Mineralogist Crystal Structure Database. Available at: http://rruff.geo.arizona.edu/ AMS/amcsd.php

15. Integrated Database of Raman Spectra.: X-ray diffraction and chemistry data for minerals. Available at: http://rruff.info/

16. Le Saout, G., Kocaba, V., Scrivener, K.L.: Application of the Rietveld method to the analysis of anhydrous cement. Cem. Concr. Res. 41, 133-148 (2011) 
17. Kulik, D.A., Wagner, T., Dmytrieva, S.V., Kosakowski, G., Hingerl, F.F., Chudnenko, K.V., Berner, U.R.: GEM-selektor geochemical modeling package: Revised algorithm and GEMS3K numerical kernel for coupled simulation codes. Comput. Geosci. 17, 1-24 (2013)

18. Vance, K., Kumar, A., Sant, G., Neithalath, N.: The rheological properties of ternary binders containing Portland cement, limestone, and metakaolin or fly ash. Cem. Concr. Res. 52, 196207 (2013)

19. Vance, K., Aguayo, M., Oey, T., Sant, G., Neithalath, N.: Hydration and strength development in ternary Portland cement blends containing limestone and fly ash or metakaolin. Cem. Concr. Comp. 39, 93-103 (2013)

20. Antoni, M., Rossen, J., Martirena, F., Scrivener, K.: Cement substitution by a combination of metakaolin and limestone. Cem. Concr. Res. 12, 1579-1589 (2012)

21. Damidot, D., Glasser, F.P.: Investigation of the CaO-A12O3-SiO2-H2O system at $25{ }^{\circ} \mathrm{C}$ by thermodynamic calculations. Cem. Concr. Res. 25, 22-28 (1995) 